\title{
A ESTRUTURAÇÃO EM "DUPLEX" DOS GNAISSES, GRANITOS MILONÍTICOS E METASSEDIMENTOS NA REGIÃO DO CERRO DOS PORONGOS, RS
}

F.M.Mello ${ }^{1}$

R.Machado ${ }^{2}$

A região do Cerro dos Porongos, situada no município de Pinheiro Machado-RS, há décadas desafia os pesquisadores da área geológica pela complexidade petro-estrutural ali existente. Situada na porção meridional da Serra das Encantadas, faz parte do Cinturão Dom Feliciano, representante sulino da orogenia Brasiliana. Esta região tem sido interpretada como uma faixa metassedimentar de baixo grau metamórfico, fortemente deformada. Trabalhos recentes realizados na região de Santana da Boa Vista-RS reinterpretaram exposições de "meta-arcóseos" como granitos milonfiticos, estruturados em nappes. A partir deste novo enfoque iniciou-se um trabalho de mapeamento geológico sistemático da área do Cerro dos Porongos, constatando-se que ali também se encontram granitos róseos, alcalinos com bandas quartzosas dobradas que também foram mapeados como metassedimentos.

A região em pauta pode ser dividida em duas unidades litoestruturais principais:(i) uma unidade inferior, em fácies anfibolito, constituída por gnaisses, granitos miloníticos, associados a xistos feldspáticos, cálcio-silicáticas, anfibolitos, meta-ultramáficas e mármores; (ii) e outra unidade superior, em fácies xisto-verde, constituída por xistos finos, quartzitos puros, sericiticos e feldspáticos. metavulcânicas e metacalcários.

Estas unidades foram submetidas a um forte regime de deformação dúctil, com todas as suas implicações físico-químicas (e.g. segregação de elementos móveis, tais como silica, processos de recristalização dinâmica, cominuição mineral...) produzindo, em consequência, uma

\footnotetext{
1Pós-graduaçăo, Departamento de Geologia Geral, Instituto de Geociências, USP.

2Departamento de Geologia Geral, Instituto de Geociências, USP.
} 
grande mudança nos protólitos, tanto no aspecto textural como composicional, resultando num conjunto bastante heterogêneo complexamente imbricado tectonicamente.

São reconhecidos regionalmente quatro grupos de estruturas de deformação, sendo dois deles precoces e dois tardios. Ao grupo precoce associam-se uma marcante foliação milonftica anostomosada, em geral de baixo ângulo, de direção NE e mergulho para sul; lineações mineral e de intersecção, caindo para sul; dobras apertadas a isoclinais, transpostas, com charneiras espessadas, em alguns casos com flancos inversos rompidos, superfícies axiais com caimento suave para sul e eixos subparalelos às lineações. São encontrados S-L tectonitos nas zonas de máxima deformação dúctil, por onde foram carreadas massas mais preservadas da deformação. Estas deformações precoces conferem ao conjunto uma estruturação em "duplex", onde rochas da unidade inferior (de mais alto grau metamórfico) recobrem as rochas da unidade superior (de mais baixo grau metamórfico). Isto corresponde a um "detachment" de rochas do embasamento (unidade inferior) sobre rochas supracrustais (unidade superior) acompanhadas da colocação de corpos graniticos controlados estruturalmente.

grupo de estruturas tardias redobra as estruturas anteriores, gerando dobras em diferentes escalas (meso e macro) que resultam entre si num padrão de interferência do tipo 1 , de domos e bacias. As estruturas deste grupo foram acompanhadas inicialmente por zonas de cisalhamento de alto ângulo associadas a grandes transcorrências, as quais condicionam em grande parte as bacias molássicas tardi-orogênicas. 